\title{
MENGINGAT dan MELUPAKAN
}

\section{MUSEUM KAPAL SAMUDRARAKSA SEBAGAI RUANG KONSERVASI KREATIF BUDAYA MARITIM}

\author{
Asyhadi Mufsi Batubara ${ }^{1}$ \\ Mahasiswa S2 Arkeologi Fakultas Ilmu Budaya Universitas Gadjah Mada \\ didi_roten@yahoo.co.id
}

\begin{abstract}
Abstrak : Pelayaran kapal Samudraraksa menuju Afrika adalah pemicu lahirnya Museum Samudraraksa. Pesan yang disampaikan didalamnya bertujuan untuk membentuk memori kolektif dan mengingat momen pelayaran Samudraraksa. Namun sebagai ruang konservasi kreatif dengan tujuan membentuk memori kolektif, ternyata masih ada hal-hal yang terlupakan sehingga kinerjanya belum optimal. Pengamatan langsung dan penerapan kajian museum studies, yang dalam hal ini menggunakan prinsip new museum merupakan metode penelitian yang dipilih untuk mengungkap fenomena tersebut. Adapun hasil kajian fakta di lapangan menyimpulkan bahwa perlu adanya tindakan evaluasi model komunikasi, serta memikirkan kembali arah dan tujuan Museum Samudraraksa di masa depan, apakah akan tetap statis atau memilih dinamis? Dengan demikian perannya sebagai ruang konservasi kreatif bisa menjadi lebih optimal.
\end{abstract}

Kata kunci: Museum, Maritim, Komunikasi, Konservasi.

\begin{abstract}
Abstracs : The voyage of the Borobudur ship to the African Continent is the inspiration for the establishment of the Samudraraksa Museum. The establishment of the museum is to shape and recreated the memory of the Samudraksa voyage. However, since the main purpose of a museum is to create a collective and creative conservational space, this has cause the output to leave out some of the important things thus cause it to be less optimal. The method that is use in this study is the direct observation and application concept on the museum studies based on the new museum principle. The findings from the field works, shows that there is a dire need for an action to re-evaluate the communication model used, in addition the purpose and goal of the Samudraraksa museum in the future need to be reconsidered, whether it will remain static or to be more dynamic? Until it able to function Samudraraksa Museum optimally as the creative conservative space.
\end{abstract}

Keywords: Museum, Maritime, Communication, Concervation.

Kami datang dari laut, tapi kami tidak mengenal laut Kami lahir dekat sekali dengan laut, tapi kami bukan bagian dari laut Kami putra ombak yang terhempas air pasang.. terseret jauh hingga daratan Kami syair lautan yang terputus dari deburan. . hilang jejak dari sejarah yang panjang Kami dahulu adalah putra ombak.. datang dari laut dan terlahir dekat sekali dengan laut. Lihatlah kami, lihatlah laut kami. Lautku kaya, tapi kami miskin Lihatlah kami, lihatlah sekolah kami. Ikan adalah barang mahal, tapi buku kami tak mampu beli. Kami adalah putra ombak, sampai hari dimana kami akan bangkit kembali

1 Mahasiswa Pascasarjana Ilmu Arkeologi Universitas Gadjah Mada, yang memiliki minat dan perhatian besar terhadap kemaritiman. Penulis juga aktif dalam bidang kajian museologi serta konservasi benda cagar budaya. 


\section{Latar Belakang}

Philip Beale ${ }^{2}$, pada kunjungan pertamanya ke Candi Borobudur di tahun 1982 langsung terpukau melihat relief kapal bercadik Candi Borobudur ${ }^{3}$. Relief itu begitu menginspirasi dan membangkitkan rasa ingin tahu Beale, sehingga di tahun 2003 Beale mewujdukan impiannya untuk melakukan rekonstruksi budaya bahari dengan berlayar menggunakan kapal bercadik menuju Afrika. Perlu diketahui bahwa pengkajian Candi Borobudur telah di mulai sejak jaman kolonial Belanda, namun perhatian khusus terhadap relief kapal yang berjumlah kurang lebih lima belas ${ }^{4}$ panel tidak begitu mendapatkan perhatian para ahli arkeologi, perkapalan, ataupun ahli sejarah di Indonesia. Cukup ironis, karena kemunculan dan keberadaan Candi Borobudur tentu tidak terlepas dari pengaruh aktivitas pelayaran dan perdagangan pada masa itu. Seperti yang pernah diungkapkan A.B. Lapian, bahwa sejarah Nusantara sama dengan sejarah maritim (Lapian, 2011: 26). Dalam artian bahwa perjalanan sejarah dan perkembangan kebudayaan Nusantara tidak terlepas dari keberadaan laut, dan sungai yang menghubungkannya dengan wilayah pedalaman ${ }^{5}$.

Banyak bukti sejarah maupun bukti etnografis yang memperkuat keberadaan aktifitas pelayaran dan perdagangan masyarakat Nusantara ke Afrika pada masa lalu. Bukti tersebut dapat dilihat dari pengaruh budaya Nusantara dalam bentuk seni musik, bahasa, dan teknologi perkapalan pada masyarakat pesisir pantai Afrika (Dick-Read, 2005) ${ }^{6}$. Dick-Read dalam bukunya "Penjelajah Bahari"7 menyebutkan bahwa

2 Philip Beale merupakan mantan angkatan laut kerajaan Inggris yang gemar mengarungi lautan dengan kapal-kapal kuno. Setelah ekspedisi kapal Samudraraksa, Beale kembali mengarungi lautan dengan kapal Poenicia.

3 Berdasarkan hasil wawancara dengan para crew kapal Samudraraksa, Muhammad Habibie, Sherly, juga diperkuat dengan laporan pada media elektronik dan informasi yang tertera pada Museum Samudraraksa.

4 Relief kapal pada Candi Borobudur bisa dikategorikan ke dalam tiga jenis bentuk kapal (1) perahu lesung, (2) kapal besar tidak bercadik, (3) kapal besar bercadik (Lapian, 2008: 21).

5 A. B Lapian. Sejarah Nusantara: Sejarah Bahari: Dalam Ilmu Pengetahuan Budaya dan Tanggung Jawabnya "Nalekta Pemikiran Guru Besar FIB UI". UI Press. Depok, 2011.

6 Dapat dilihat melalui jenis alat musik xilofon (gambang) pada relief Candi Borobudur juga dikenal di masyarakat Kamerun (gong ganda), Zimbabwe (timbila chopi), atau pada jenis cadik perahu Madagaskar yang berbentuk ganda menyerupai cadik Nunantara (Dick-Read, 2005)

7 Robert Dick-Read. Penjelajah Bahari: Pengaruh Peadaban Nusantara di Afrika. Mizan. Bandung, 2005.

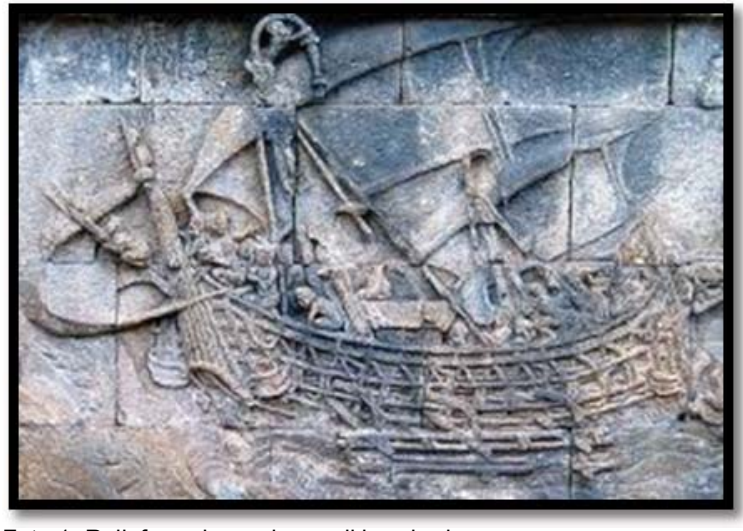

Foto 1. Relief perahu pada candi borobudur.

interaksi antara pelaut Nusantara dengan masyarakat pesisir di benua Afrika telah berlangsung sejak awal abad masehi ${ }^{8}$. Pernyataan ini diperkuat oleh catatan sejarah yang menunjukkan besarnya permintaan pasar terhadap komoditas kayu manis atau cinnamon telah mendorong para pelaut Nusantara untuk berdagang hingga Afrika.

Beberapa ahli pelayaran dan perdagangan kuno, seperti Y.P. Maguin, Knaap, maupun Lapian menyebutkan, bahwa gambaran kapal bercadik pada relief Candi Borobudur kemungkinan merupakan cikal bakal kun lun $p o^{9}$ atau junk java ${ }^{10}$ yang di masa awal pelayaran antar samudera digunakan untuk menjelajah ke berbagai benua. Dengan kata lain, kemungkinan kapal bercadik telah ada jauh sebelum Candi Borobudur dibangun dan telah menginspirasi berbagai bentuk kapal dibelahan dunia yang lain. Kapal bercadik bisa jadi kapal pelopor pelayaran antar samudera pelaut Nusantara, dan hal ini kemudian kembali dibuktikan dalam ekspedisi jalur cinnamon ${ }^{11}$ yang dipimpin Beale. Inti dan makna pelayaran kapal

8 Bukti ini diperkuat dengan laporan-laporan para penjelajah asing seperti Pliny dalam 'natural history (23-79 M), juga didukung para ahli seperti George Hourani ahli kelautan Arab, E. H Wellington ahli perdagangan Romawi/India dll (Dick-Read, 2005).

9 Kun lun po, sebutan bangsa China kepada pelaut-pelaut Nusantara. Kun lun berarti penyebutan untuk pelaut dari Nusantara, dan Po berarti kapal.

10 Junk java apabila di ibaratkan dengan alat tranformasi modern zaman sekarang, sama dengan pesawat air bus yang mampu mengangkut banyak orang dan banyak muatan. Laporan ini diperkuat berdasarkan catatan China, seperti pada catatan pendeta It-sing yang pada waktu itu melakukan perjalanan dari Sriwijaya hendak ke India (Dick-Read, 2005).

11 Bahasa latin dari kayu manis, tanaman yang banyak tumbuh di hutan-hutan pedalaman kepulauan Nusantara, dan telah menjadi komoditas ungulan yang diperdagangkan hingga ke Romawi dan Yunani sejak awal abad masehi (Turner, 2011) 


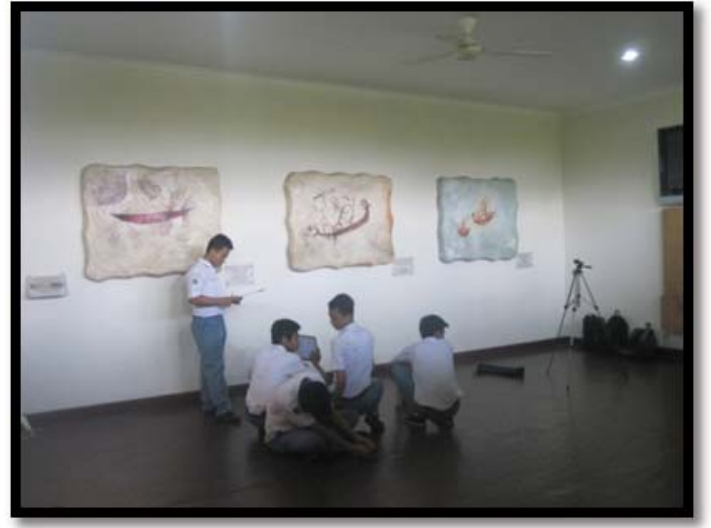

Foto 2. Suasana pada salah satu ruang museum

Samudraraksa bukan hanya sekedar rekonstruksi budaya bahari dan romantisme kejayaan masa lalu, namun yang lebih penting adalah pelayaran tersebut sebagai upaya konservasi kreatif budaya bahari yang kini mulai hilang dalam alam budaya masyarakat Nusantara.

Pelayaran kapal Samudraraksa sebagai suatu upaya rekonstruksi dan konservasi juga bertujuan untuk membuktikan pada dunia dan masyarakat Indonesia, bahwa kejayaan maritim Indonesia bukan hanya sebatas catatan sejarah. Kapal yang diberi nama Samudraraksa ${ }^{12}$ mencoba membuka mata dan ingatan kita, bahwa ada hal penting lain yang telah mulai hilang dari alam kebudayaan dan memori kolektif bangsa Indonesia, yakni budaya bahari Nusantara. Kita juga hampir memungkiri bahwa kita adalah negara kepulauan, suatu negara yang memiliki potensi untuk tumbuh besar sebagai kekuatan maritim dunia ${ }^{13}$. Melalui momen tersebut kapal Samudraraksa kembali mengingatkan seganap masyarakat bahwa perlu adanya upaya serius untuk kembali mengingatkan publik bahwa sumber daya laut merupakan peluang sekaligus tantatangan terbesar yang harus dikembangkan. Pemahaman yang menganggap laut sebagai living monument dan ruang belajar harus ditumbuhkan dalam mindset publik.

Museum Samudraraksa hadir sebagai solusi, jawaban dan sebagai tempat untuk mengingat segala hal yang telah terlupakan. Namun apakah Museum Samudraraksa telah menyampaikan pesan terkait kapal bercadik Samudraraksa secara utuh? Apakah museum telah menjadi ruang konservasi kreatif

12 Diambil dari bahasa Sansekerta yang berarti penjaga lautan.

13 Primada Tabrani. Belajar dari Sejarah dan Lingkungan “edisi ke-2”. Institut Tekhnologi Bandung. Bandung, 2011. budaya maritim yang mampu membawa perubahan sosial dan mindset publik?

\section{Museum Samudraraksa Sebagai Ruang Konservasi Kreatif}

Pagi itu petugas Museum Samudraraksa disibukkan oleh rombongan anak sekolah yang berasal dari beberapa daerah di Jawa Barat. Suasana ceria tiba-tiba memadati ruang pameran yang menampilkan kapal legendaris Samudraraksa. Decak kagum mucul atas pesona yang dipancarkan kapal Samudraraksa. Jelas sekali keberadaan kapal Samudraraksa mampu membangkitkan imajinasi terliar para pengunjung akan petualangan laut yang penuh tantangan. Sosok uniknya membuat pengunjung berkhayal jauh ke masa lampau, sembari menerka-nerka bagaimana tekhnik navigasi dan pelayaran yang digunakan pada masa itu. Bertamasya ke Museum Samudraraksa layaknya seperti berjalan melintasi ruang tanpa batas waktu, bermain ke masa lalu untuk mengintip pijakan di masa depan.

Museum Samudraraksa bukan hanya sekedar bangunan yang menyimpan memori kolektif bangsa Indonesia yang telah dirajut dari masa ke masa. Lebih dari itu museum tersebut meruapakan ruang budaya yang tersusun dan menyusun satu momen ke momen lainnya. Lebih tepatnya merupakan ruang konservasi kreatif budaya bahari Nusantara bersifat tangible dan Intangible secara berkesimabungan. Berawal dari gambaran kondisi soial budaya masyarakat Nusantara abad ke-8 $\mathrm{M}$ yang dipahatkan dalam bentuk relief yang kemudian menginspirasi Beale unuk melakukan upaya rekonstruksi budaya maritim Nusantara. Perubahan peran dan fungsi tersebut dapat dilihat dalam Bagan 1.

Pada akhirnya kapal Samudraraksa yang pernah mengharumkan nama Indonesia atas prestasinya, kini beralih fungsi sebagai masterpiece Museum Samudraraksa. Ditinjau dalam pengertiannnya museum bisa dimaknai sebagai ruang konservasi budaya yang berperan untukmengedukasiserta merawat kelestarian kapal Samudraraksa dari sisi tangible dan intangible. Seperti yang telah dirumuskan oleh ICOM $^{14}$, bahwa museum melestarikan, menafsir, dan membina serta mempromosikan warisan alam dan budaya manusia ${ }^{15}$. Museum juga bertanggung jawab atas warisan alam dan budaya baik yang berwujud maupun yang tidak

14 ICOM (International Council Of Museum) merupakan lembaga permuseuman internasional.

15 Pada poin satu ICOM. 


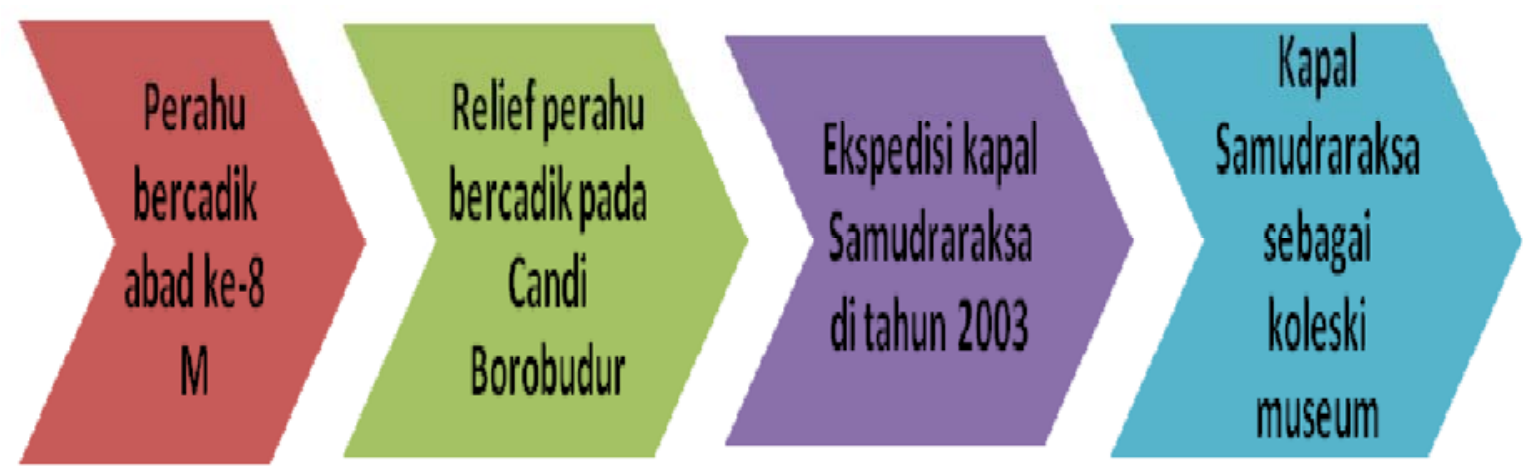

Bagan 1. Proses perubahan peran dan fungsi perahu bercadik pada relief Candi Borobudur.

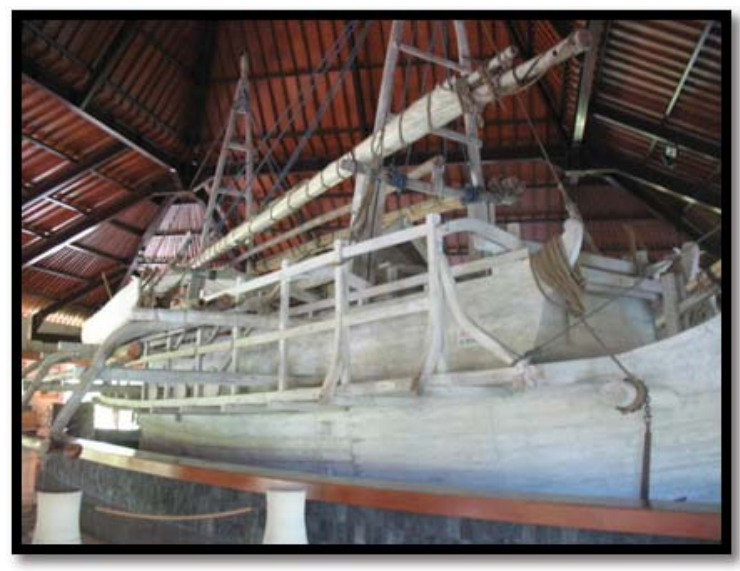

Foto 3. Kapal Samudraraksa sebagai koleksi museum

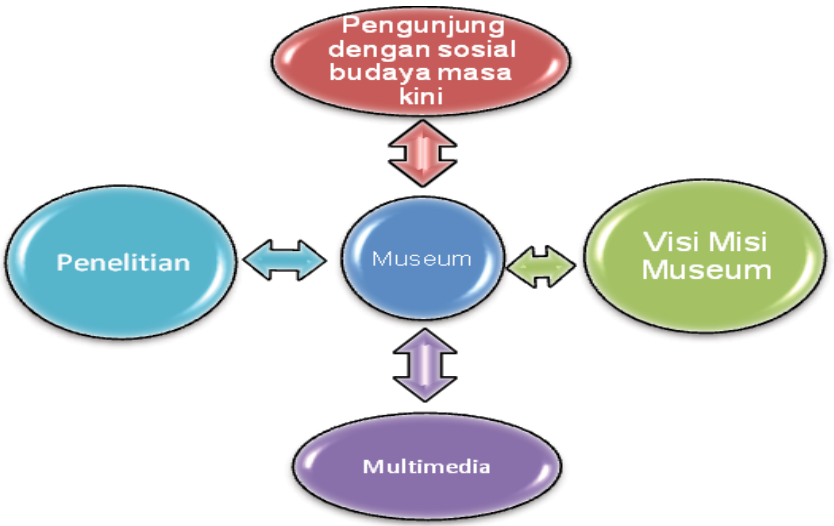

Bagan 2. Pola Edukasi dan komunikasi dua arah dalam museum sebaga ruang konservasi kreatif

memori kolektif guna pencapaian cita-cita bersama. Hal ini dikarenakan terbentuknya museum ${ }^{18}$, baik dalam model museum tradisiona ${ }^{19}$ maupun museum modern dengan penggunaan multimedia, museum tetap mampu merepresentasikan sejarah serta pemikaranpemikiran yang memaknainya secara philosofis dengan cara yang menarik dan edukatif ${ }^{20}$. Adapun gambaran pola edukasi dan komunikasi museum diuraikan dalam bagan 2 .

Hanya saja masalah muncul ketika kita terlalu mengingat satu hal namun melupakan yang lain. berpendapat bahwa, museum merupakan alat pendidikan zaman modern yang paling efektif. Museum sebagaimana kedudukannya sebagai alat pendidikan zaman modern senantiasa akan menyesuaikan dengan perkembangan dunia modern itu sendiri ${ }^{17}$. Melihat sifatnya yang bersentuhan langsung dengan masyarakat luas, maka museum juga berperan sebagai ruang publik yang dijadikan sebagai media pembentuk wacana dan

16 Merupakan asas museum berdasarkan rumusan ICOM.

17 Sutan Takdir Alisjahbana. Museum Sebagai Alat Pendidikan Zaman Moderen. Jakarta: Penerbit Pustaka Rakjat. 1954. hal. 7.
18 Sekilas sejarah museum, sebelum bersifat terbuka untuk umum museum hanyalah konsumsi masyarakat kelas atas. Namanya sendiri diambil dari bahasa Yunani 'Mouseion' yakni bermakna kuil untuk memuja. Berdasarkan artefaktual yang bisa terlacak, museum diperkirakan telah ada sejak abad ke-2 M di Mesopotamia (Burcaw, 1984: 17). Sedangkan keberadaan museum mulai dibuka untuk publik dimulai pad abad ke-18 di Eropa. Dimana pada masa ini pengaruh modrnisasi tengah bergejolak dan didukung dengan revolusi Perancis (Habermas, 2012).

19 Museum yang menyajikan koleksi sebagai object oriented dengan pesan yang terbatas sehingga lebih mirip encyclopaedy (Magetsari, dalam museografia Vol V No.7, 2011)

20 Dalam Mensch, 2011: 10. 
Dengan kata lain, terkadang pihak museum melupakan nilai esensial dan hakekat museum sebagai ruang konservasi kreatif yang seharusnya melayani dan berkomunikasi dua arah dengan publik ${ }^{21}$. Alhasil konservasi budaya bahari yang berperan menanamkan mindset dan menggugah kesadaran kemaritiman pengunjung justru tidak berjalan maksimal. Model komuniaksi satu arah merupakan model komunikasi museum yang masih bersifat tradisional. Paradigma permuseuman kini telah diganti dengan paradigma yang dikenal dengan istilah new museum. Paradigma baru ini justru lebih menakankan perhatian kepada pengunjung dan bukan kepada koleksi ${ }^{22}$. Hal ini tercermin dalam tata pamernya atau ekshibisnya yang lebih berorientasi kepada publik dengan cara mengangkat perkembangan isu-isu terkait, sehingga museum senantiasa bersifat dinamis ${ }^{23}$. Ruang-ruang Museum Samudraraksa memang secara khusus diperuntukkan sebagai media komunikasi antara relief perahu bercadik Borobudur dengan ekspedisi kapal Samudraraksa ke Afrika. Namun sebagai ruang konservasi kreatif seharusnya pesan yang dikomunikasikan tidak terhenti sampai disitu saja, akan tetapi harus terus berkembang menyesuaikan isu-isu terkait tema yang sama.

Nama Samudraraksa sendiri memiliki arti sebagai penjaga lautan. Sama halnya dengan museum yang juga bisa dimaknai sebagai penjaga kelestarian budaya maritim. Sehinggaruang MuseumSamudraraksa perlu mennginformasi kegiatan-kegitatan pelayaran yang berhubungan dengan perkembangan kebaharian guna membangkitkan semangat kemaritiman. Seperti misalnya pelayaran kapal Majapahit keliling Asia pada tahun 2010, pelayaran Kapal Pemuda Nusantara yang digelar setiap tahunnya, ekspedisi pelayaran Sabang Merauke, dan pelayaran lainnya. Oleh karena itu patut untuk dipertimbangkan kembali apakah Museum Samudraraksa dalam peran dan fungsinya sebagai penjaga dan pengembang budaya maritim masih tetap

$21 \quad$ Komunikasi dua arah dalam museum dilakukan untuk melihat respon serta kritik saran pengunjung yang kemudian akan dijadikan sebagai landasan evaluasi museum. Model komunikasi ini dikenal dengan istilah umpan balik yang diperkenalkan oleh Knez \& Wright di tahun 1970 (Hooper-Greenhill, 2004: 46)

22 Selain perhatiannya lebih menekankan kepada pengunjung, new museum juga berorientasi pada model komunikasi dua arah. Lebih lengkapnya Lihat Hauenschild, 1988: 5-6. 23 Lihat Davis, 2007: 56, dan Desertasi Andrea Hauenschild yang berjudul "Claim and Reality of New Museology: Case Studiesin Canada, The United State, and Mexico" Hamburg University, 1988. memilih komunikasi statis atau beralih ke dinamis? Apabila memilih dinamis maka Museum Samudraraksa harus menyuguhkan komunikasi dua arah yang edukatif dan interaktif. Model komunikasi dua arah dapat diaplikasikan melalui museum experience yang ditawarkan kepada pengunjung baik dalam bentuk hands on, puzle, games, permaianan bajak laut atau dalam bentuk kegiatan kemaritiman.

Melalui media interaktif pengunjung akan semakin terinspirasi sehingga secara perlahan mampu membawa perubahan pada pola pikir ke arah kemaritiman. Media komunikasi museum memang dirancangan untuk mudah dimengerti, yakni dengan penyajian display yang menarik, label yang edukatif, sehingga museum menjadi ruang yang tepat untuk mempelajari budaya melalui pesan-pesan yang
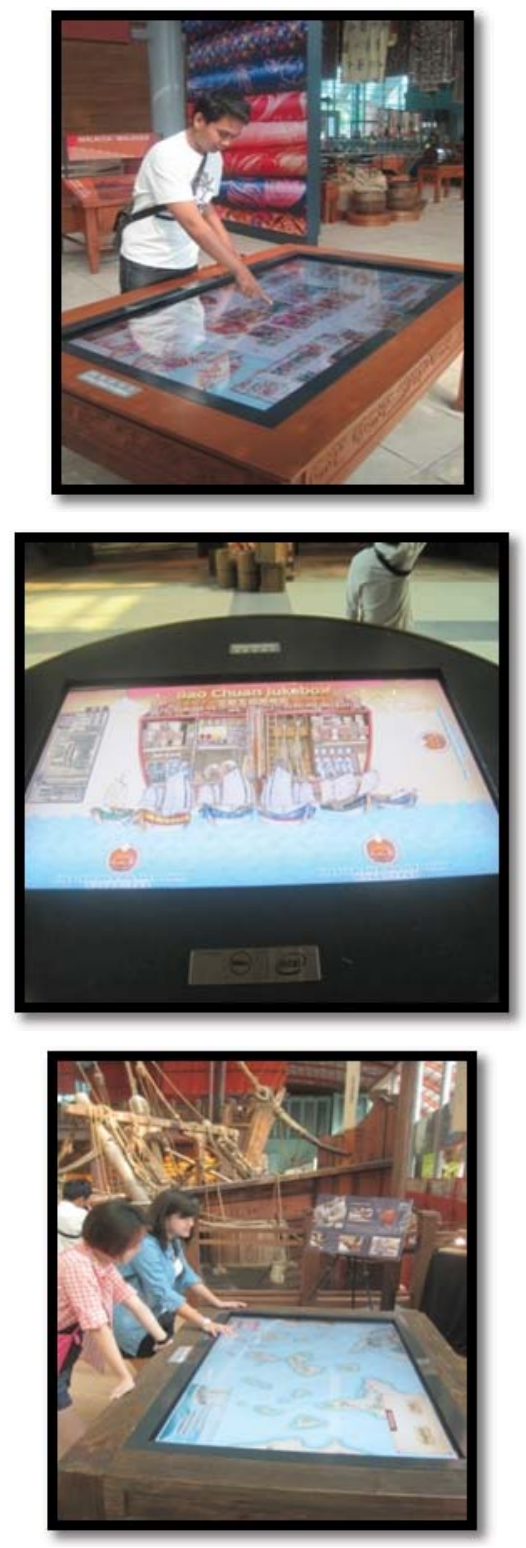

Foto 4. Media edukasi interaktif dalam bentuk permainan pada Maritime Museum Singapore 
terkandung dalam koleksinya ${ }^{24}$. Nilai edukasi yang dipadukan dengan unsur hiburan menjadikan Museum Samudraraksa sebagai ruang konservasi budaya maritim. Namun untuk semakin mengoptimalkan upaya konservasi tersebut, perlu dirancang programprogam yang mengarah kepada penanaman mindset dan kesadaran maritim, baik dalam bentuk kegiatan bulanan atau tahunan. Namun bagian ini sepertinya terlupakan dalam Museum Samudraraksa. Ketiga hal penting yang telah dipaparkan sebelumnya berperan sangat penting dalam pembentukan ruang museum sebagai ruang konservasi kreatif.

Upaya mengoptimalkan Museum Samudraraksa menjadi museum yang berkualitas, menginspirasi dan mampu membawa perubahan sosial akan semakin penting untuk masa yang akan datang. Mengingat bahwa museum pada era milenium baru akan menjadi tempat penting berkumpulnya manusia. Prediksi ini dilandasi adanya kecendrungan masyarakat yang selalu berkeinginan untuk mengenali dan melongok "rumah tetangganya" dalam desa dunia ini, dimana museum dilihat sebagai jendela untuk mengenali budaya lain ${ }^{25}$. Museum Samudraraksa dalam peranannya sebagai jendela peradaban dan kebudayaan maritim Indonesia, harus mulai ditangani secara serius serta dioptimalkan fungsinya sebagai ruang konservasi budaya maritim.

\section{Museum (memori + kreativitas) $=$ Perubahan Sosial ${ }^{26}$}

Kunjungan Philip Beale ke Candi Borobudur di tahun 1982 ternaya telah menanamkan sebuah memori yang kuat. Berawal dari memori kemudian melahirkan sebuah gagasan ekspedisi kapal Samudraraksa menuju Afrika. Hasil perpaduan memori dan kreatifitas Philip Beale tersebut ternyata juga mempengaruhi memori publik. Sebut saja misalnya Muhammad $\mathrm{Habibie}^{27}$ yang kemudian berdasarkan perpaduan memori dan kreatifitas menuliskan kisah perjalanannya sebagai anggota crew kapal Samudraraksa kedalam sebuah novel berjudul "GofarWest:151HariMenantang Badai".

$24 \quad$ Dalam Greenhill, 2007: 370.

25 Lebih lengkapnya lihat Daud Aris Tanudirjo. Menuju Kebangkitan Permuseuman Indonesia. Dalam Seminar Reposisi Museum di Indonesia. Jakarta, 2008.

26 Tema Museum Internasional 2013.

27 Salah satu crew Kapal Samudraraksa yang mewakili pemuda indonesia yang ikut berlayar dari Madagaskar ke Agra. Habibie merupakan alumni ITS Jurusan Teknik Perkapalan.
Novel ini kemudian menginspirasi Prof. Primadi Tabrani $^{28}$ yang mengaitkan ekspedisi Samudraraksa dengan kajian ilmiah dalam bukunya yang berjudul "Belajar dari Sejarah dan Lingkungan"29. Perpaduan memori dengan kreatifitas ini juga dihadirkan dalam Museum Samudraraksa dengan tujuan yang sama, yakni meciptakan memori kemaritiman kepada pengunjung dengan harapan akan menghasilkan kreatifitas lain. Terbukti efek menginspirasi Museum Samudraraksa terus berlanjut, bahkan juga menginspirasi penulis untuk melakukan hal yang sama di tahun $2010^{30}$. Museum Samudraraksa dengan perpaduan memori dan kreatifitas mampu menanamkan memori kolektif kebaharian kepada setiap pengunjung. Harapannya akan menginspirasi anak bangsa lainnnya seperti Muhammad Habibie, Prof. Tabrani, penulis, untuk mengolah memori tersebut dengan kreatifitas masingmasing sesuai bidangnya guna menciptakan perubahan sosial.

Dalam peranannya sebagai pembawa perubahan sosial, Museum Samudraraksa menitikberatkan pada upaya merajut memori kolektif yang dapat diingat bersama ${ }^{31}$. Seperti yang disebutkan Abidin Kusno dalam bukunya, bahwa pelupaan bisa terjadi akibat adanya campur tangan negara dan kelompok penguasa untuk menciptakan memori kolektif tertentu ${ }^{32}$. Sebagai ruang publik yang berperan besar membentuk memori kolektif, museum juga berperan dalam proses pelupaan kolektif ${ }^{33}$. Seperti yang telah dipaparkan dalam bab sebelumnya, bahwa ada hal-hal yang terlupakan dalam Museum Samudraraksa. Hal terlupakan tersebut perlu dikaji ulang.

Hal penting lainnya yang perlu diperhatikan adalah kedudukan Museum Samudraraksa yang tergolong sebagai museum minoritas, karena \pm 400 museum bertema umum di Indonesia hanya terdapat \pm 4 museum yang secara khusus bertema maritim. Kondisi yang tidak seimbang ini memunculkan suatu

28 Prof. Primadi Tabrani merupakan dosen ITB yang kemudian menulis buku Belajar dari Sejarah dan Lingkungan. Penerbit ITB. Bandung, 2011.

29 Primadi Tabrani. Belajar dari Sejarah dan Lingkungan. Penerbit ITB. Bandung, 2011.

30 Penulis mengikuti ekspedisi kapal layar Majapahit di tahun 2010.

31 Dalam Abidin Kusno. Ruang Publik, Identitas, dan Memori Kolektif: Jakarta Pasca Suharto. Penerbit Ombak. Yogyakarta, 2009.

32 Ibid.

33 Ibid. 
pemikiran, apakah kita memang sengaja melupakan budaya maritim? Abidin Kusno dalam bukunya ${ }^{34}$ mengatakan, bahwa kehadiran memori kolektif tergantung kepada keberadaan ruang publik yang memberi tempat untuk merajut memori kolektif. Masalah apa yang akan muncul ketika ruang publik tersebut hilang, atau ketika ruang publik sama sekali tidak pernah dihadirkan? ${ }^{35}$. Jawaban singkatnya adalah, tentu akan terlupakan.

Revolusi atau mati. Dalam remukmu, kau dipaksa bangkit atau tidak sama sekali Revolusi atau mati. Biru pun kini jadi kelabu, membeku dalam ketidak tahuanmu

Revolusi atau mati. Lautan telah lama berseru, menderu bagai ombak Latsefa membangunkan tidur panjangmu. Revolusi atau mati. Penjelajah bahari tewas ditembak resolusi 1787, bahkan hingga detik ini pun masih dininabobokkan iklan di tivi. Revolusi atau mati. Kembalilah menjadi bangsa samudera. Bangkit sekarang, atau tidak sama sekali

\section{Daftar Pustaka}

Alisjahbana, S. Takdir. 1954. Museum Sebagai Alat Pendidikan Zaman Modern. Pustaka Rakjat. Jakarta.

Ammarell, Gane. 2008. Navigasi Bugis. Hsanuddin University Press. Makasar.

Burcaw, G Ellis. 1984. Introduction to Museum Work. The American Association for State and Local History. Nashville.

Davis, Peter. 2007. Place Exploration: Museum, Identity, Community " dalam Museum and Their Comunity ed Sheila Watson. Routledge. New York.

Direktorat Jenderal Permuseuman. 2011. Sejarah Permuseuman Di Indonesia. Jakarta.

Greenhill, Eilean Hooper. 2007. Museum and Education: Purpose, Pedagogy, Performance. Routledge. New York.

\section{Penutup}

Museum dalam teknik penyajiannya hadir dengan memuat memori (dalam bentuk koleksi museum, label teks, audiavisual, replika serta diorama) untuk membantu pengunjung mengingat momenmomen yang dapat diingat bersama. Oleh karena itu publikmembutuhkan museum bertema maritim seperti Museum Samudraraksa sebagai tempat untuk merajut memori kolektif kemaritiman. Namun terkadang dalam ruang pembentuk memori kolektif tersebut ternyata masih ada hal-hal yang terlupkan sehingga kinerjanya sebagai ruang konservasi kreatif belum maksimal. Paradigma permuseman sendiri juga telah mengalami perubahan, beralih dari object oriented menjadi public oriented. Kehidupan sosial budaya masyarakat juga mengalami perubahan dari tahun ke tahun. Terjadinya perubahan-perubahan tersebut mengakibatkan perlu adanya tindakan evaluasi model komunikasi pada Museum Samudraraksa agar tetap senantiasa berfungsi secara maksimal. Hal lain yang perlu dipertimbakan kembali adalah tujuan Museum Samudraraksa ke masa depan, apakah akan tetap hanya menyajikan pesan hanya sampai pada kisah pelayaran ekspedisi ke Afrika, atau museum akan hadir dalam bentuk yang lebih dinamis?

2007. Museum, Media, Message. Routledge. New York.

2004. Museum and Their Visitor. Rotledge. New York.

Habermas, Jurgen. 2012. Ruang Publik: Sebuah Kajian Tentang Kategori Masyarakat Borjuis. Kreasi Wacana. Yogyakarta.

Haunschild, Andrea.1988. Claim and Reality of New Museology: Case Studies in Canada, The United State, and Mexico "Desertasi Doktor Hamburg University". Hamburg.

Lapian, A.B. 2008. Pelayaran dan Perniagaan Nusantara: Abad Ke-16 dan 17. Komunitas Bambu. Jakarta.

2011. Sejarah Nusnatara : Sejarah Bahari "dalam buku Analekta Pemikiran Guru Besar FIB UI (Ilmu Pengetahuan Budaya dan Tanggung Jawabnya)". Universitas Indonesia. Depok.

$\begin{array}{ll}34 & \text { ibid. } \\ 35 & \text { Ibid. }\end{array}$


Kusno, Abidin. 2009. Ruang Publik, Identitas, dan Memori Kolektif: Jakarta Pasca-Suharto. Penerbit Ombak. Yogyakarta.

Mensch, Peter Van. New Trends in Museology. 2011. Museum of Recent History Celje. Slovenia.

Read, Robert Dick. 2008. Pengaruh Peradaban Nusantara di Afrika: Penjelajah Bahari. Mizan. Bandung.

Tabrani, Primadi. 2011. Belajar dari Sejarah dan Lingkungan: Ekspedisi Borobudur. Penerbit ITB. Bandung.
Tanudirjo, Daud Aris. 2008. Menuju Kebangkitan Permuseuman Indonesia "Makalah Seminar Reposisi Museum Di Indonesia". Jakarta.

Turner, Jack. 2011. Sejarah Rempah: Dari Eksotisme Sampai Imprealisme. Komunitas Bambu. Depok.

\section{WEBSITE}

www.icom.com

www.asosiasimuseumindonesia.org 